\title{
Cytotoxic Activity Screening of Fungal Extracts Derived from the West Sumatran Marine Sponge Haliclona fascigera to Several Human Cell Lines: Hela, WiDr, T47D and Vero
}

\author{
Dian Handayani", Wildan Rasyid', Rustini', Elmi Nurhaidah Zainudin², Triana Hertiani ${ }^{3}$ \\ 'Faculty of Pharmacy, Andalas University, Padang 25163, Indonesia. \\ ${ }^{2}$ Faculty of Marine Science and Fisheries, Hasanuddin University, Makassar, indonesia. \\ ${ }^{3}$ Faculty of Pharmacy, Gadjah Mada University, Sekip Utara, Yogyakarta, Indonesia.
}

\begin{tabular}{l}
\hline ARTICLE INFO \\
\hline Article history: \\
Received on: 07/05/2017 \\
Accepted on: 08/06/2017 \\
Available online: $28 / 01 / 2018$ \\
\hline Key words: \\
Cytotoxic activity, Haliclona \\
fascigera, marine derived \\
fungi, Brine Shrimp Lethali- \\
ty Test (BSLT), MTT assay \\
\hline
\end{tabular}

\section{INTRODUCTION}

In recent years, cancer has become the most deadly diseases of man. According to the World Health Organization (WHO), cancer has become one of the major causes of morbidity and mortality throughout the world and there were approximately 14 million new cases and 8.2 million cancer-related deaths in 2012. In Indonesia, the prevalence of cancer was 1.4 per 1000 population, or around 330 thousand people (Basic Health Research, 2013). The number of cancer patients in Indonesia was very high. This can be seen from various cancer data published by both government and cancer institutions. Even according to the WHO in 2030 will be a surge in cancer patients in Indonesia up to seven times. The number of cancer patients who died is also increasingly

"Corresponding Author

Dian Handayani, Faculty of Pharmacy, Andalas University, Padang, Indonesia.

E-mail:dianh_17@yahoo.com apprehensive. For many years cancer researchers around the world have been focused on finding better therapeutic strategies and new molecular approaches to reduce mortality. Nowadays there is a considerable scientific discovery of new anticancer agents from natural products, one of which was marine sponge.

Sponges are one group marine organisms contained in the waters of Indonesia by amount of about 850 kinds (Van Soest, 1989). The content of sponge's secondary metabolites was reported to have wide range of bioactivity which was promising for development as the lead compound (Edrada et al., 2000). Sponges have tissues and organs that are very simple and have varied shapes. Sponge growth is strongly influenced by the chemical and physical environment, such as the: the depth, the waves, and sedimentation. Sponges are also a very fertile host to a wide range symbiotic microorganisms, like bacteria and fungi.

These microbes live and attached to the sponge and interacted symbiotic mutualism. The existence of microbial symbiotic function are in assisting process of acquiring nutrients (especially in the fixation of carbon and nitrogen), the allocation of the com- 
pounds of defense, synergies between the chemical structural, stabilizer skeletons sponge, and assist the process of excretion as well as contribute in the production cycle of secondary metabolites (Hentscel et al. 2002). Thus, it can be assumed that symbiotic microbes produce a secondary metabolite similar to a sponge. Microbial symbiotic can produce bioactive compounds with huge potential to develop into a new drug compounds.

This study was a continuous study to investigate the antibacterial and cytotoxic activity of ethyl acetate extract obtained from marine derived fungi of the sponge from West Sumatera, Indonesia. Examination of cytotoxic activity was performed by BSLT and MTT assay methods (Handayani et al., 2015a; Handayani et al., 2015b; Handayani et al., 2016a; Handayani et al., 2016b).

\section{MATERIALS AND METHODS}

\section{Sponge material}

The sponge $H$. fascigera was collected from the Setan Island in Februari 2015, at South Coast of West Sumatra, Indonesia, in depth of $\pm 13 \mathrm{~m}$. The Sponge was taken $200 \mathrm{~g}$ and transferred into a sterilized plastic bag and stored in the ice box. The sample was transported to the laboratory and processed immediately for the isolation of symbiotic fungi.

\section{Isolation of marine derived fungi from sponge $\boldsymbol{H}$. fascigera}

The isolation of symbiotic fungi was started by surface sterilization of the sample. The sponge was rinsed with sterile seawater, and then cut into small pieces and was taken as much as 10 grams an inserted into Erlenmeyer flask and $100 \mathrm{~mL}$ of sterile seawater was added. Then it was diluted until its concentration $10^{-6}$ and inoculated on Sabouraud Dextrose Agar (SDA) containing chloramphenicol $(0.05 \mathrm{~g} / \mathrm{L})$ as medium, and incubated at a temperature of $27-29^{\circ} \mathrm{C}$ for 5-7 days. Colonies that have different shapes and colors with other colonies could be regarded as different isolates. Then the isolates were purified by the scratch method to obtain pure isolates (Kjer et al, 2010). The Pure isolate was identified based on Brigitte (1980). The isolated fungi have been deposited at our laboratory in Sumatran Biota Laboratory, Andalas University.

\section{Cultivation of isolated fungi in medium of MEB}

Each of the pure fungal isolate obtained in the insulating phase was cultured in medium of Malt Extract Broth (MEB). The fungal was taken one loop, then put in a $50 \mathrm{ml}$ MEB medium and incubated at room temperature for 7 days. Furthermore, they were grown on a scale of $50 \mathrm{ml}$ were transferred aseptically similar to the culture medium at a larger scale $(500 \mathrm{ml})$ and incubated at room temperature for 3-4 weeks (Kjer et al, 2010).

\section{Extraction of secondary metabolites from fungal isolates}

The fungal isolates at their maximum growth were then extracted with ethyl acetate (EtOAc) in 3 repetitions. The ethyl acetate extract was collected and evaporated in vacuo using a rotary evaporator (Kjer et al, 2010). The concentrated EtOAc extracts were tested for cytotoxic activity using method of BSLT. Based on cytotoxic test results on BSLT method, fungal extract which has a $\mathrm{LC}_{50}<100 \mathrm{ppm}$ was continued to test by determining the percentage of viability against three cancer cells and normal cells with MTT assay method. The $\mathrm{IC}_{50}$ determination was done for extract with a low percentage of viability.

\section{Screening of toxicity and cytotoxic activities}

\section{BSLT method}

The BSLT assay is non-specific toxicity assay that is used in natural products to detect the presence of bioactive compounds. In this assay was used the nauplii of Artemia salina $\mathrm{L}$ (Artemiidae). Brine shrimp eggs were hatched in $500 \mathrm{~mL}$ of filtered seawater under constant aeration for $48 \mathrm{~h}$ at $(27 \pm 2)^{\circ} \mathrm{C}$. After hatching, active nauplii of the egg cell are collected and used for testing. Five hundred, fifty, and five $\mu \mathrm{l}$ of all fungal ethyl acetate extracts were added to the vials. After the solvent was dry, $50 \mu \mathrm{l}$ DMSO was added and supplemented with $5000 \mu \mathrm{l}$ of seawater, resulting in final concentration of $1000 \mathrm{ppm}, 100 \mathrm{ppm}$ and $10 \mathrm{ppm}$ in triplicate. Ten nauplii are then inserted into each vial and kept at room temperature for 24 hours. The filtered seawater and DMSO are used as negative controls. The $\mathrm{LC}_{50}$ value is calculated using curve method based on probit analysis (Meyer et al., 1982).

\section{MTT assay}

Sample screening

4 cell lines, HeLa as cervix cell line, WiDr as a colon adenocarcinoma cell line, T47D as human ductal breast epithelial tumor cell line and Vero as normal cell line have been prepared for cytotoxic assay using MTT. All cell lines were obtained from Laboratory of Parasitology at UGM. Hela, T47D and WiDR were cultured in RPMI 1650 and Vero was cultured in M199 Medium. All cells were subculture after mild trypsinization with trypsin-EDTA (Sigma-Aldrich, USA), and then determined the cell number and viability. The cells were seeds in 96-well plates at density $6 \times 10^{3}$ cells/well in 100 $\mu 1$ medium and incubated overnight. All media were supplemented at $10 \%$ with fetal bovine serum (Gibco) and streptomycin and penicillin ( $2 \%$, Sigma-Aldrich, USA). The cell line were kept at $37^{\circ} \mathrm{C}$, $98 \%$ relative humidity with $5 \% \mathrm{CO}_{2}$ atmosphere.

A stock solution was prepared by dissolving the samples in DMSO and was given 100.000 ppm concentration. Cells that had been incubated 24 hours, then divided into several groups, namely treatment, positive control, cell control and media control (blank). Removed medium and washed using PBS sterile which each well was add $100 \mu \mathrm{l}$ PBS. Then, $100 \mu \mathrm{l}$ of each material (extract) added to each well with one concentration (100 ppm). As control positive was used by doxorubicin. Then it was incubated for 24 hours in an incubator at $37^{\circ} \mathrm{C}, 5 \% \mathrm{CO}_{2}$.

Cells that had been treated and incubated 24 hours later dumped throughout the medium and washed using sterile PBS. Then in each well was added $100 \mathrm{~mL}$ of MTT $(5 \mathrm{mg} / \mathrm{ml})$ followed by a 4 hour incubation in an incubator at $37^{\circ} \mathrm{C}, 5 \% \mathrm{CO}_{2}$. To each well was added $100 \mu \mathrm{l}$ of $10 \%$ SDS to dissolve the formazan crystals formed and incubated one night in room temperature. The plates were then read by ELISA reader at $540 \mathrm{~nm}$ (Permanasari et al., 2016)

$\%$ Cell viability then calculated by the equation

$$
\frac{\text { OD of treatmnet }- \text { OD of blank }}{\text { OD of control }- \text { OD of blank }} \times 100 \%
$$


The aim of this screening was to identify which sample was given cytotoxic activity in cell line.

\section{Cytotoxic assay}

Cytotoxic assay was determination by $\mathrm{IC}_{50}$ which was made by the same procedure as sample screening. Fungi extracts were made in several concentrations which are $300,150,75,37.5$, 18.75 and $9.375 \mathrm{ppm}$. Doxorubicin as a positive control was created in concentration of $100,50,25,12.5$ and $6.25 \mathrm{ppm}$.

\section{Statistical methods}

Value Ln concentration is regressed against cell viability. Regression equations were then used to calculate $\mathrm{IC}_{50}$ values. Another method that can be used to calculate the $\mathrm{IC}_{50}$ values are probit analysis using SPSS.

\section{RESULTS AND DISCUSSION}

Marin fungi that are associated with marine sponge can be derived from the environment in which the sponge arise through the process of filter feeder, and enter into mesophyll. However, some studies show that besides microbial episimbion attached to the surface of the sponge during the growing period (Chelossi et al., 2004), some bacteria and yeasts (fungi) transmitted genetically in the body of the sponge (Maldonado et al., 2005).

21 fungi were successfully isolated from the marine sponge Haliclona fascigera collected from the waters of Setan Island, in West Sumatra at a depth of 13 meters. The fungi isolates were cultivated in a liquid medium, Malt Extract Broth (MEB) for 30-40 days. Ethyl acetate extract of fungal isolates ranged from 15.4-551.3 mg.

The examination results the toxicity activity by the method of Brine Shrimp Lethality Test showed that the $\mathrm{LC}_{50}$ of ethyl acetate extract of fungi isolates ranges from 1 to $335 \mathrm{ppm}$. According to Meyer et al. (1989), extracts of plants or animal are classified a cytotoxic when the $\mathrm{LC}_{50}$ value $<1000 \mathrm{ppm}$. An extract is considered very toxic when it has a $\mathrm{LC}_{50}$ value $<30 \mathrm{ppm}$, and toxic if it has a $\mathrm{LC}_{50}$ value $30-1000 \mathrm{ppm}$ and is considered nontoxic if $\mathrm{LC}_{50}>1000 \mathrm{ppm}$. While pure compound was declared toxic if it has a value of $\mathrm{LC}_{50}<200 \mathrm{ppm}$ (Meyer, 1982). Therefore, extract of WR4, WR8, WR13, and WR19 with $\mathrm{LC}_{50}$ value of $<10$ can be categorized as toxic and should be followed up in order to find a potential anti-cancer compound (Figure 1).

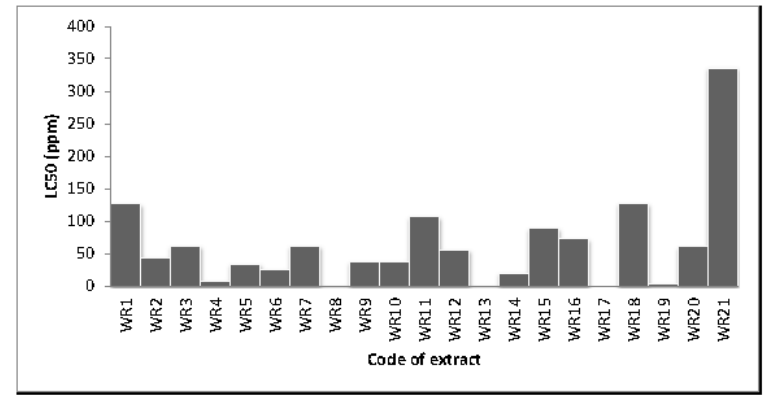

Fig. 1: Brine shrimp toxicity results $\left(\mathrm{LC}_{50}\right.$ in $\left.\mathrm{ppm}\right)$.
The BSLT is found to have a good correlation with cytotoxic activity in some human solid tumors and with pesticide activity, and led to the discovery of new class of natural pesticides and active antitumor agent (Mc Laughlin et al., 1998). The cytotoxic activity of the drug can affect and disrupt the fundamental mechanisms associated with cell growth, mitotic activity, differentiation and function. The results of the cytotoxic activity for this extract may be due to one of these mechanisms.

Further testing of cytotoxic test was conducted by MTT assay. This method is a colorimetric method, in which the MTT reagent is a tetrazolium salt that can be broken down into formazan crystals by succinate tetrazolium reductase. This enzyme is present in active mitochondria and plays a role on cell respiration cycle. Formazon purple crystals can be read its absorbance by using ELISA reader (Doyle and Griffith, 2000). NADH or other reductor might be transfer the electron into MTT and made formazon purple crystal (Berrigde et al., 1993).

Cytotoxic activity of the compounds can be determined based on the value of $\mathrm{IC}_{50} . \mathrm{IC}_{50}$ is the concentration of the extract/ test compounds that can kill as many as $50 \%$ of the cell population. The determination of $\mathrm{IC}_{50}$ value begins with determining of the viability percentage of cancer cells in the culture medium after adding ethyl acetate extract of symbiotic fungal with a concentration of $100 \mu \mathrm{g} / \mathrm{ml}$.

Fungi extract with the lowest percentage of viability $(\leq 50 \%)$ especially against the HeLa cancer cells are extracts WR2, WR4, WR6 and WR9 (Figure 2). The percentage of viability extracts against other cancer cells (WIDR, T47D and Vero) is highly variable and some of which are not toxic to the normal cells (vero).

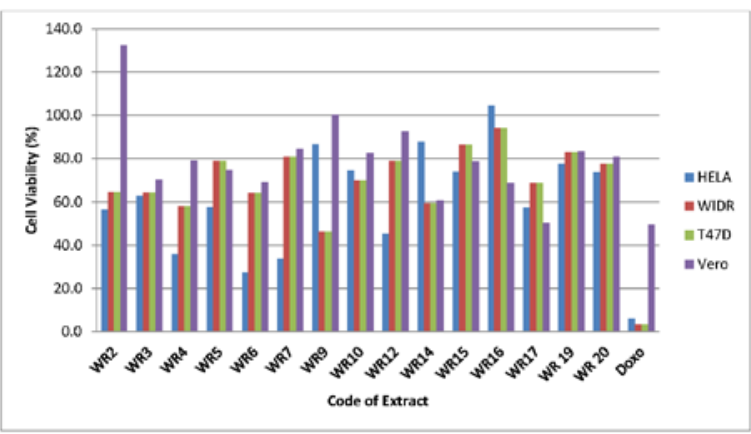

Fig. 2: Cytotoxic effect of ethyl acetate extracts on various cancer cell lines

Determination of $\mathrm{IC}_{50}$ value is then performed to extracts which shows the lowest of the viability percentage of above. Data obtained from several concentrations of the extract was analyzed by linear regression equation to obtain $\mathrm{IC}_{50}$ values. $\mathrm{IC}_{50}$ extract values of WR2, WR4, WR6 and WR9 against HeLa, WIDR, T47D and Vero cell lines were different for each other (Table 1). Based on Table 1, it can be determined that the most cytotoxic extract against all cancer cell cultures compared with extract of WR2, WR4 and WR9 was extract of WR6. The cytotoxic activity of WR6 extract is quite selective against WIDR only, when it compared with the cytotoxic activity of doxorubicin against all cancer cells even the normal cells (vero cells).

The four fungi above were selected for further characterization and identification based on Brigitte (1980). Macroscopic 
examination includes a visual observation to the form colony or hyphal, surface and reverse colony color, and colony texture. While on microscopic examination was carried out by observing the characteristic of the spores or conidia, and reproductive structures (sexual and asexual) under a light-field microscope. Based on the results of the morphological identification of four fungal isolates which showed cytotoxic activity, it is known that the fungus WR2 is Trichophyton sp, WR4 is Aspergillus sp, WR6 is Trichophyton sp and WR9 is Penicillium sp.

Table 1. $\mathrm{IC}_{50}$ of selected fungal extracts on various cancer cell lines.

\begin{tabular}{lccccc}
\hline No. & Code of Extract & \multicolumn{4}{c}{ IC $_{\mathbf{5 0}}$ of Cancer and Normal Cell Line (ppm) } \\
\hline \multirow{2}{*}{1} & WIDR & T47D & Hela & Vero \\
2 & WR2 & 193.95 & $5,861.67$ & 211.55 & 357.49 \\
3 & WR4 & 38.21 & 328.23 & 598.89 & 321.54 \\
4 & WR6 & 47.36 & 67.08 & 118.29 & 342.94 \\
5 & WR9 & 284.28 & 132.74 & 118.29 & 342.94 \\
\hline
\end{tabular}

In this preliminary study, it can be conclude that the cytotoxic activity can be produced from secondary metabolites contained in the extract of the fungus. The results of this study provide important information for the continued research on isolation, and characterization of cytotoxic compounds from WR6 and other extracts. Therefore, this fungal extract can be developed as a source of candidate for new drugs in overcoming the problem of cancer.

\section{CONCLUSIONS}

This study demonstrated that several EtOAc extracts of the fungi derived from marine sponge Haliclona fascigera were cytotoxic. The results indicated that fungal isolates of WR2, WR4, WR6 and WR9 may be useful as an alternative to produce the anticancer used in pharmaceutical. However, further research needs to be done in determining of anticancer compounds produced by those marine sponge derived fungi.

\section{CONFLICT OF INTERESTS}

Declared none.

\section{ACKNOWLEDGEMENT}

This research was funded by Directorate General of Higher Education Ministry of National Education, Indonesia, in project "International Research Collaboration and Publication, No: 059/SP2H/LT/DPRM/IV/2017.

\section{REFERENCES}

Berridge MV, Tan AS. Characterization of the cellular reduction of 3-(4,5-dimethylthiazol 2-yl)-2,5-diphenyltetrazolium bromide (MTT): subcellular localization, substrate dependence, and involvement of mitochondrial electron transport in MTT reduction. Arch Biochem Biophys 1993; 303(2):474-82.

Brigitte, G. Kompendium der medizinischen mykologie. 1980, Berlin-Hamburg. Verlag Paul Parey.
Chelossi E, Milanese M, Milano A, Pronzato R, \& Riccardi G. Characterisation and antimicrobial activity of epibiotic bacteria from Petrosia ficiformis (Porifera, Demospongia). J. Experimental Mar Biol \& Ecol, 2004; 309: 21-33.

Doyle A, and Griffiths JB. 2000. Cell and tissue culture for medical research. New York: John Willey and Sons Ltd.

Edrada RA, Wray V, Handayani D, Schupp P, Balbin-Oliveros M, and Proksch, P. Structure-activity relationships of bioactive metabolites from some Indo-Pacific marine invertebrates. Studies in Natural Products Chemistry 21(B). 2000; 251-292. ISSN 1572-5995.

Handayani D, Sandrawaty N, Murniati M, and Regina R. Screening of Endophytic Bacteria Isolated from Marine Sponge Haliclona fascigera for Inhibition against Clinical Isolates of Methicillin Resistant Staphylococcus aureus (MRSA). J. of Applied Pharmaceutical Science, 2015a; 5(9): 139-142.

Handayani D, Ahdinur, RF, and Rustini R. Antimicrobial Activity of Endophytic Fungi from Marine Sponge Haliclona fascigera. Journal of Applied Pharm. Science, 2015b; 5(10), 154-156

Handayani D, Ornando R and Rustini, Antimicrobial Activity Screening of Symbiotic Fungi from Marine Sponge Petrosia nigrans collected from South Coast of West Sumatera Indonesia, International Journal of Pharmacognosy and Phytochemical research, 2016a; 8(4): 623-625.

Handayani D, Murniati M, Rustini R, In vitro inhibitory activity of ethyl acetate extract of symbiotic bacteria isolated from the marine sponge Haliclona fascigera against multidrug resistant organism (MDRO). Journal of Applied Pharm. Science, 2016b; 6(11):218-222.

Hentschel U, Piel J, Degnan, SM, and Taylor MW. Genomic insights into the marine sponge microbiome. Nature Reviews Microbiology, 2012,10:641-654.

Kjer J, Debbab A, Aly AH, Proksch P. Methods for isolation of marine-derived endophytic fungi and their bioactive secondary products Nature Protocols, 2010,5(3): 479-490.

Meyer BN, Ferrign RN, Putnam JE, Jacobson JE, Nicholas DE, McLaughlin JL, Brineshrimp: a convenient general bioassay for active plant constituents. Planta Medica, 1982, 45, 31-34.

Maldonado M, Corrtadellas N, Trillas MI, \& Rützler C. Endosymbiotic yeast matternally transmitted in a marine sponge. Biol Bull. 2005, 209: 94-106.

McLaughlin JL, Rogers LL, Anderson JE, The Use of Biological Assays to Evaluate Botanicals. Drug Information Journal, 1998, 32, 513 524.

Permanasari P, Hertiani T, Yuswanto A. Immunomodulatory Effect of Massoia Bark Extract and The Cytotoxicity Activiy Against Fibroblast and Vero Cells in Vitro. International Journal of Pharmaceutical and Clinical Research, 2016; 8(5) Suppl:326-330.

Reports the Results of Basic Medical Research. 2013. Research and Development Agency for Health, Ministry of Health, Republic of Indonesia.

Van Soest RW. 1989. The Indonesian Sponge Fauna: A Status Report. Institute of Taxonomic Zoology, University of Amsterdam.

How to cite this article:

Handayani D, Rasyid W, Rustini, Zainudin EN, Hertiani T. Cytotoxic Activity Screening of Fungal Extracts Derived from the West Sumatran Marine Sponge Haliclona fascigera to Several Human Cell Lines: Hela, WiDr, T47D and Vero. J App Pharm Sci, 2018; 8 (01): 055-058. 